\title{
SOME CONSIDERATIONS REGARDING THE NATURAL HABITATS FROM PESCEANA FOREST (ROMANIA)
}

\author{
Monica Angela Neblea ${ }^{1, *}$, Roxana Ciobanu ${ }^{1}$, Mădălina Cristina Marian ${ }^{1}$ \\ ${ }^{1}$ University of Pitesti, Targu din Vale street, no. 1, Pitesti, Romania
}

\begin{abstract}
A phytosociological study of the vegetation from Pesceana forest (Vâlcea county) is presented in this paper. The purpose of this study was to characterize the natural habitat 91 Y0 Dacian oak-hornbeam forests. This natural habitat have a remarkable floristic structure, in some stations with representative populations of Cephalanthera longifolia and Epipactis helleborine.

The conservative status is not favourable, especially due to illegal logging which, in some areas, has favored soil erosion, the spreading of invasive species and the change of the specific floristic composition.

Some measures of conservation are needed to maintain a favourable status of conservation, such as: monitoring of forestry activities; banning the grazing in the forest; planting with native characteristic species in areas affected by deforestation; prohibition the collecting of biological material, especially orchid species; monitoring touristic activities; monitoring and control of invasive species.
\end{abstract}

Keywords: forest habitat, Pesceana, Romania, Vâlcea

\section{INTRODUCTION}

The forest as a complex ecosystem will always be an invaluable resource for society, both for the it products, but especially for its beneficial effects on the environment. In Romania, forest management is based on a unitary system of technical forestry, economic and legal rules regarding the management, culture, exploitation, protection of the national forest fund. This will ensure the sustainable management of forests, regardless of the nature property (Bozga et al., 2009).

Pesceana forest is located on the hills of the Getic Plateau region, in the Oltet Piedmont, southern part of Vâlcea County. The geological substratum dates from the Pliocene period, being predominated by sands, clays and their alternations. The predominant landforms are the low and middle hills. The altitude of the studied territory varies between $200 \mathrm{~m}$ and $500 \mathrm{~m}$ ("Râpa Cărămizii" area). The hydrographic network is mainly represented by streams that may carry no water during the dry season. Pesceana and Negraia are the most representative streams. Pesceana forest is characterized by its peculiarities in the temperate continental climate, with warm summers and cold winters (http://www.anpm.ro/documents/29243/33287047/PUGPesceana-+primaversiune+ final.pdf/94fa080c-2fa1-43df-917b-956977802ee4; Forest Management Plan of the Pesceana V Production Unit). 
The purpose of this research was to assess the conservation status of ecosystems in the Pesceana forest (Vâlcea county) so as to develop the most appropriate measures for a rational management of the natural resources.

\section{MATERIALS AND METHODS}

Phytosociological surveys were carried out to identify natural habitats in Pesceana forest in 20192020 according to Zürich-Montpellier Central-European School methodology, adapted to the characteristics of the vegetal layer in our country.

For each survey, an area between 400 and $1000 \mathrm{~m}^{2}$ was established, making observations on the biotope and biocoenosis regarding: exposure, slope inclination, altitude, tree vegetation cover (using a scale between $0,5-1)$, herbaceous vegetation height $(\mathrm{cm})$, herbaceous layer coverage $(\%)$ and coverage of each species.

The characterization of the plant communities was realized on the basis of personal observations in the field and consulting scientific literature (Flora R.P.R. - R.S.R. (1952-1976), Oltean et al., 1994; Sanda et al., 2001; Doniţă et al., 2005; Chifu et al., 2014; Sanda et al., 2008; Gafta and Mountford coord., 2008; Sârbu et al., 2013; Forest Management of the V Pesceana Production Unit, 2019; https://ww2.bgbm.org/EuroPlusMed/query.asp).

The assessment of the conservation status of natural habitats from Pesceana forest was done using the 'semaphore method' (Combroux and Schwoerer, 2007) and recommendations from Annex no. 1 of the Guide for the elaboration of the management plans of the protected natural areas approved by the Ministerial Order no. 304/2018.

\section{RESULTS AND DISCUSSIONS}

The plant communities from Pesceana forest belong to one type of NATURA 2000 habitats, respectively 91Y0 Dacian oak-hornbeam forests. This habitat type corresponds to two natural habitats according to the Romanian classification system (Doniţă et al., 2005), which were identified in the studied area: R4126 Mixed Moldavian forests of sessile oak (Quercus petraea), beech (Fagus sylvatica) and silver linden (Tilia tomentosa) with Carex brevicollis and R4129 Dacian forests of sessile oak (Quercus petraea) and beech (Fagus sylvatica) with Festuca drymeja. There were described 7 types of forests in the forest management plan of Pesceana: 5131 Coastal sessile oak with grasses and Luzula luzuloides, 5141 Plateau sessile oak with heavy soil, 5113 Sessile oak forest with mull flora of medium productivity, 5314 Hill mixed foliage forest with sessile oak and beech of medium productivity, 5324 Hill mixed foliage forest with sessile oak of medium productivity, 5513 Sessile oak and pedunculate oak forest of medium productivity and 6121 Meadow oak forest in the hilly region.

Only 3 types of these forests have been inventoried and described in this paper: 5131 Coastal sessile oak with grasses and Luzula luzuloides, 5314 Hill mixed foliage forest with sessile oak and beech of medium productivity and 5513 Sessile oak and pedunculate oak forest of medium productivity.

\section{Description of the forest ecosystems}

R4126 Mixed Moldavian forests of sessile oak (Quercus petraea), beech (Fagus sylvatica) and silver linden (Tilia tomentosa) with Carex brevicollis

Correspondence with other habitat classification systems:

EMERALD: !41.2 Oak-hornbeam forests

CORINE: - 


\begin{tabular}{lcr}
\hline & $\begin{array}{c}\text { Current Trends in Natural Sciences } \\
\text { Vol. 9, Issue 18, pp. 139-148, 2020 } \\
\end{array}$ & $\begin{array}{c}\text { Current Trends in Natural Sciences (CD-Rom) } \\
\text { https://doi.org/10.47068/ctns.2020.v9i18.019 }\end{array}$ \\
\cline { 2 - 3 } Current Trends in Natural Sciences (on-line) & & 2284-9521 \\
ISSN: 2284-953X & & ISSN-L: 2284-9521 \\
ISSN-L: 2284-9521 & \\
\hline
\end{tabular}

PAL.HAB: 41.2C22 Moldo-Muntenian sessile oak-hornbeam forest EUNIS: G1.A1C2 Moldo-Muntenian oak-lime-hornbeam forest

NATURA 2000: 91 Y0 Dacian oak-hornbeam forests

Plant association: Aro orientalis - Carpinetum (Dobrescu et Kovacs 1973) Täuber 1992.

Forest type: 5513 Sessile oak and pedunculate oak forest of medium productivity

Site description. The vegetal grouping with hornbeam were identified in stations with different exposure (southern, eastern, western), $20-30^{\circ}$ degree of inclination and 350-400 $\mathrm{m}$ altitude. The canopy is very well developed about 0,8 . The herbaceous layer has a variable height of $10-50 \mathrm{~cm}$ and realizes a coverage between $10 \%$ and $30 \%$.

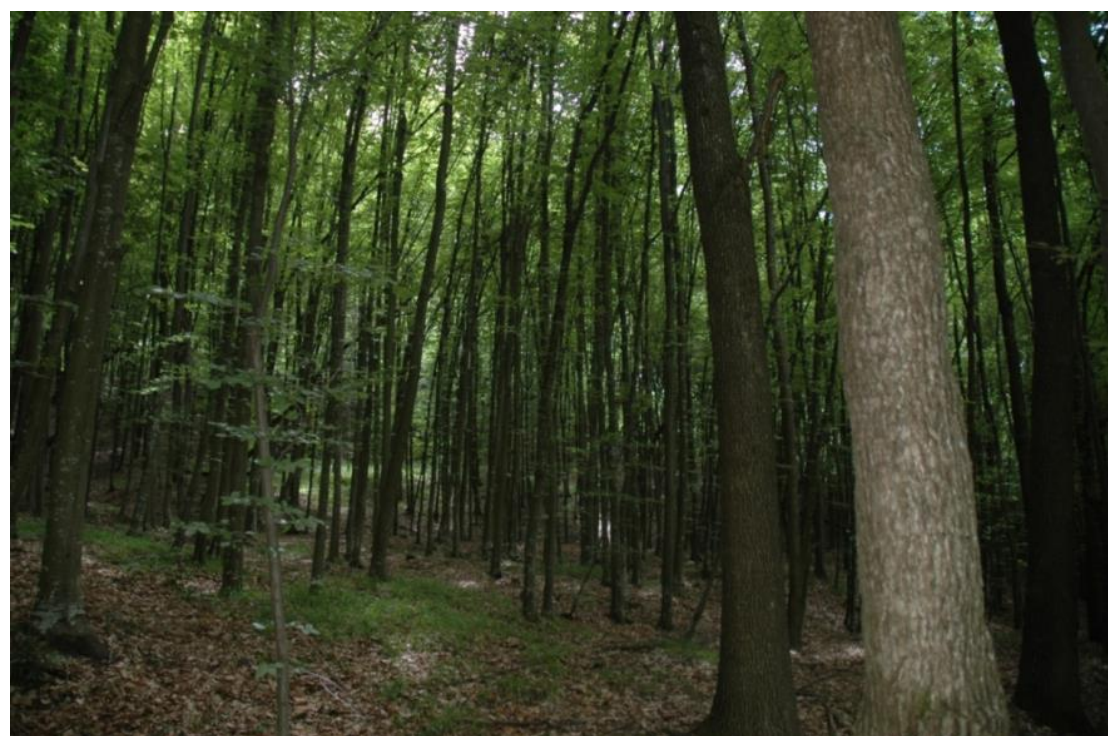

Figure 1. Aro orientalis-Carpinetum (Dobrescu et Kovacs 1973) Täuber 1992

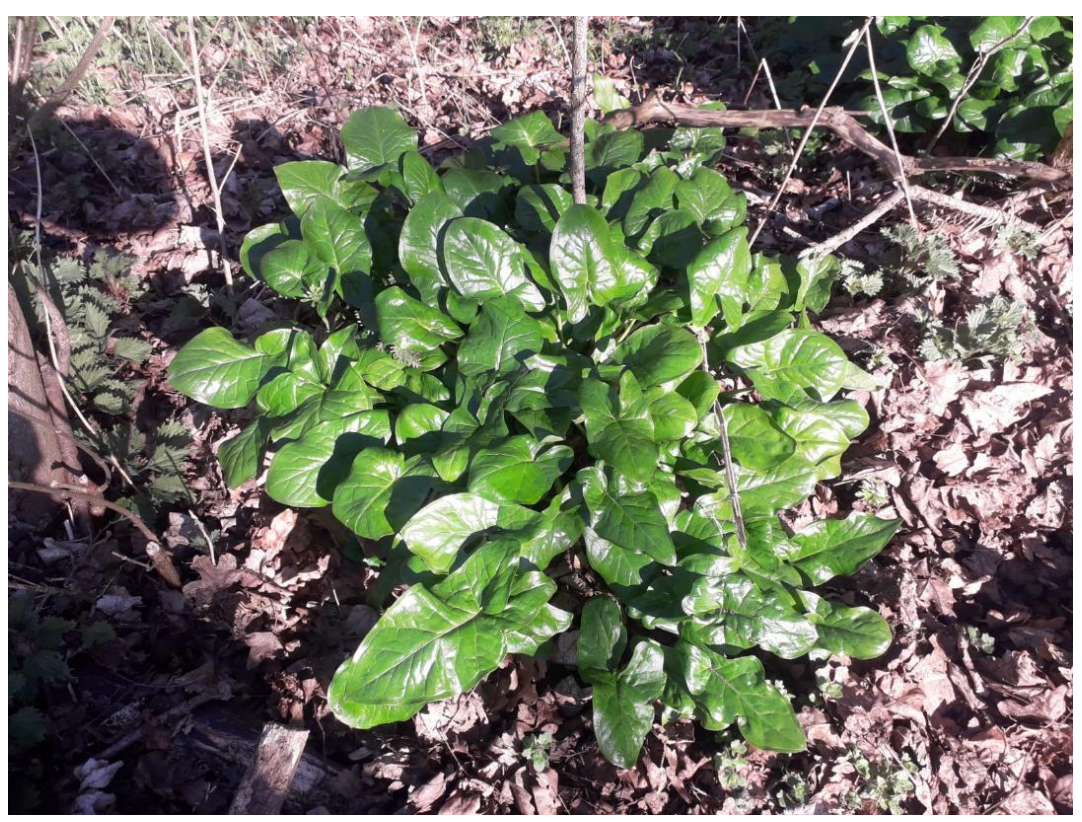

Figure 2. Arum orientale M. Bieb. 
The structure of plant community. The phytocoenoses are edified by the European and Caucasian species. The arborescent layer is dominated by Carpinus betulus, being accompanied by Quercus petraea, Fagus sylvatica, Fraxinus excelsior, F. angustifolia, Tilia platyphyllos, Prunus avium, Sorbus torminalis, Acer pseudoplatanus, Pyrus communis subsp. pyraster. Cornus sanguinea is present as arbustive species. Melica uniflora, Brachypodium sylvaticum, Dactylis glomerata have a important coverage in the aestival season. The characteristic species of these ecosystems is Arum orientale which has a coverage of $10-20 \%$ in spring.

Floristic composition. Edified species: Quercus petraea, Fagus sylvatica, Tilia platyphyllos, Fraxinus excelsior, Carpinus betulus. Other species: Prunus avium, Festuca drymeja, Melica uniflora, Dioscorea communis, Campanula rapunculoides, Melitis melissophyllum, Cardamine bulbifera, Lathyrus venetus, Euphorbia amygdaloides, Alliaria petiolata, Brachypodium sylvaticum, Sanicula europaea, Acer pseudoplatanus, Ajuga reptans, Viola reichenbachiana, Carex sylvatica, Dactylis glomerata, Sorbus torminalis, Cornus sanguinea, Geranium robertianum, Anemone nemorosa, Fraxinus angustifolia, Moehringia trinervia, Lamium galeobdolon, Symphytum tuberosum, Asarum europaeum. Robinia pseudoacacia is disseminated in these arboreta.

This habitat has a moderate conservative value. There are fairly well-preserved habitats, in which dead wood is present, "on the foot" and "on the ground" and offers favourable ecological niches for different species of insects, birds, fungi, bacteria etc.

\section{R 4129 Dacian forests of sessile oak (Quercus petraea) and beech (Fagus sylvatica) with Festuca drymeja \\ Correspondence with other habitat classification systems:}

EMERALD: !41.2 Oak-hornbeam forests

CORINE:-

PAL.HAB: 41.7A151. Getic pre-Carpathic Festuca drymeja oak forest

EUNIS: G1.8713. Pre-Carpathian beech-sessile oak forest

NATURA 2000: 91Y0 Dacian oak-hornbeam forests

Plant association: Festuco drymeiae - Quercetum petraeae Morariu et al. 1970

Forest type: 5131 Coastal sessile oak with grasses and Luzula luzuloides

Site description. The forest ecosystems with Quercus petraea vegetate on inclined moderate slopes $\left(10-20^{\circ}\right)$, with eastern exposure, at 420-450 $\mathrm{m}$ altitude. The canopy is weakly developed $(0,5-0,7)$ and favors the development of the herbaceous layer (coverage between 40-60\%) which has a height of $10-70 \mathrm{~cm}$.

There is a good regeneration both of the trees (Quercus petraea, Acer campestre, A. platanoides, Fraxinus excelsior, F. ornus, Carpinus betulus) and shrubs (Crataegus monogyna, Rosa canina), recording a coverage between $20-40 \%$.

The structure of plant community. The coenoses are dominated by Quercus petraea, along with other spread tree species, such as: Fagus sylvatica, Fraxinus excelsior, F. ornus, Carpinus betulus, Acer platanoides, A. campestre, Tilia platyphyllos, Ulmus laevis and Prunus avium. The shrubs and subshrubs layer is represented by Rubus hirtus, Rosa canina, Clematis vitalba, Sambucus nigra and Crataegus monogyna. Festuca drymeja has the highest coverage in the herbaceous layer, being accompanied by other species from Poaceae family: Poa nemoralis, Melica uniflora, Brachypodium sylvaticum, Dactylis glomerata.

Floristic composition. Edified species: Quercus petraea, Fagus sylvatica. Other species: Festuca drymeja, Prunus avium, Tanacetum corymbosum, Poa nemoralis, Cytisus hirsutus, Trifolium 


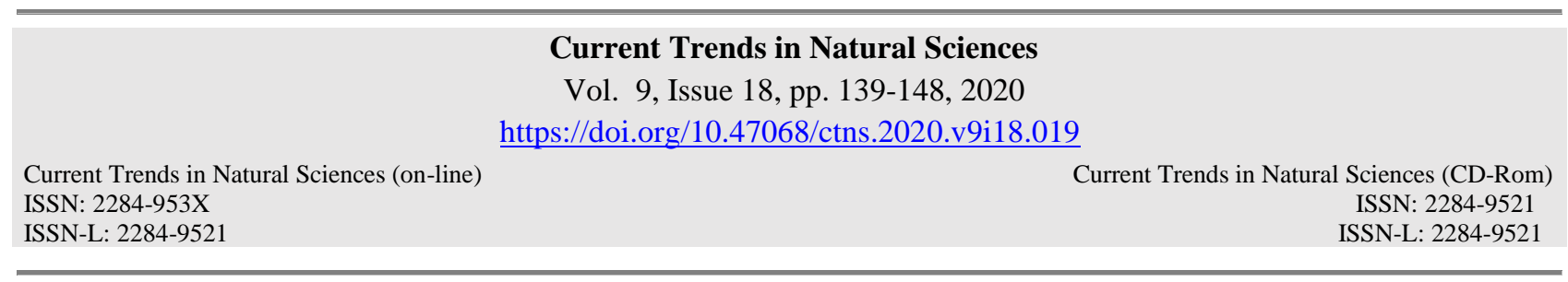

alpestre, Luzula luzuloides, Potentilla micrantha, Galium pseudoaristatum, G. intermedium, G. aparine, Lathyrus niger, L. venetus, Melica uniflora, Dioscorea communis, Campanula rapunculoides, Melitis melissophyllum, Vincetoxicum hirundinaria, Carpinus betulus, Hypericum perforatum, Scrophularia nodosa, Cardamine bulbifera, Acer platanoides, A. campestre, Fraxinus excelsior, F. ornus, Lactuca muralis, Salvia glutinosa, Rubus hirtus, Tilia platyphyllos, Euphorbia amygdaloides, Alliaria petiolata, Brachypodium sylvaticum, Crataegus monogyna, Rosa canina, Carex sylvatica, Prunella vulgaris, Genista tinctoria, Dactylis glomerata, Fragaria vesca, Glechoma hirsuta, Geum urbanum, Lysimachia nummularia, Silene coronaria, S. viscaria, Ulmus laevis, Cephalanthera longifolia, Robinia pseudoacacia.

The conservative value is moderate.

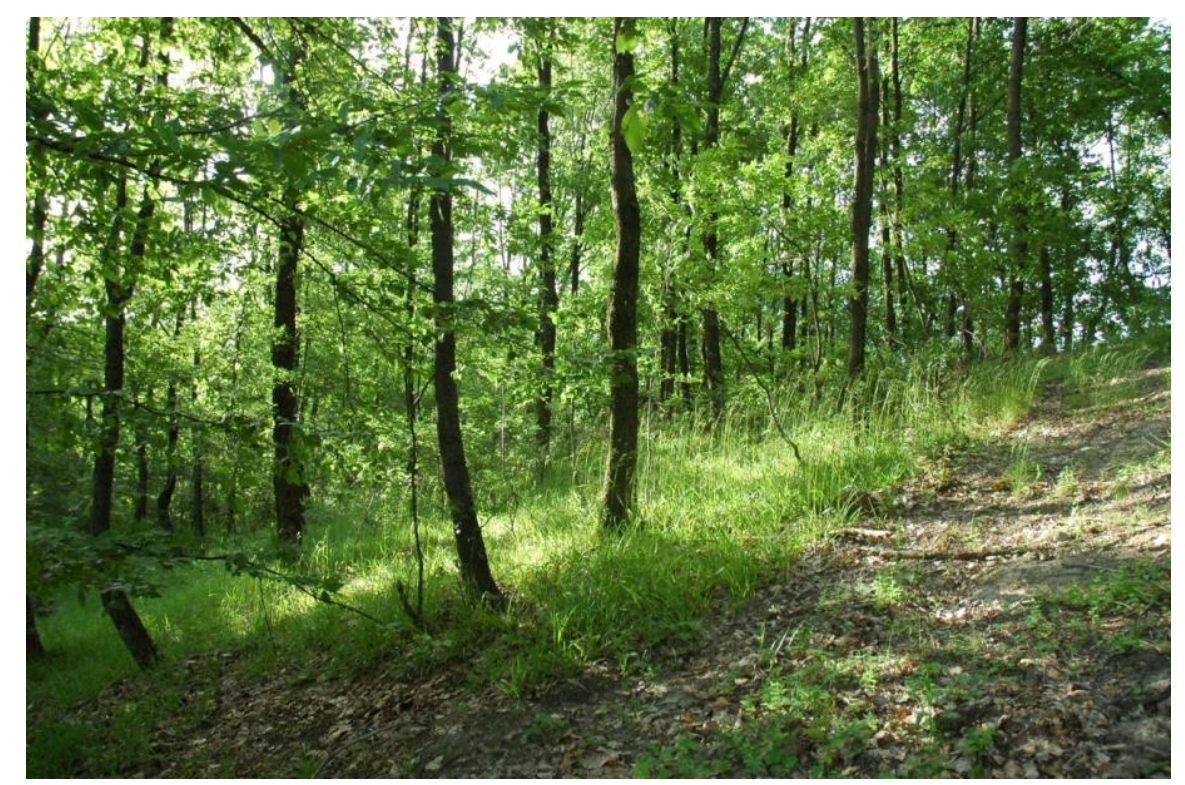

Figure 3. Festuco drymeiae - Quercetum petraeae Morariu et al. 1970

\section{Forest type 5314 Hill mixed foliage forest with sessile oak and beech of medium productivity}

Site description. The coenoses of this type of forest were observed on variously inclined slopes (10$30^{0}$ ), with predominantly southern exposure, at altitudes of 400-450 m. The canopy has a coverage of $80 \%$. The herbaceous layer is made up of species whose height varies between $20-70 \mathrm{~cm}$ and which make a coverage of $15-20 \%$.

The structure of plant community. The arborescent layer is diversified, consisting of species such as Fagus sylvatica, Carpinus betulus, Acer pseudoplatanus, A. platanoides, Tilia platyphyllos, Quercus petraea, Populus tremula, Fraxinus excelsior. Rosa canina and Crataegus monogyna are the more widespread shrubs.

Impatiens noli-tangere forms facies in the wet biotopes and its coverage reaching up to $70 \%$. There were identified some orchid species: Epipactis helleborine, Platanthera bifolia, Cephalanthera longifolia, Neottia nidus-avis.

There are areas where Robinia pseudoacacia is very abundant (30\% coverage), especially where beech was cut off.

Atropa bella-donna is a commonly species in the coenotic ambiance of this plant grouping. 


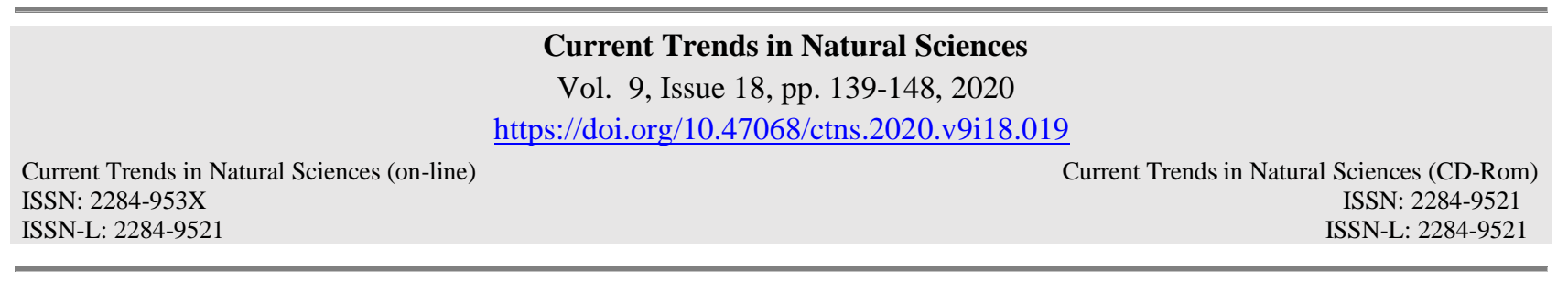

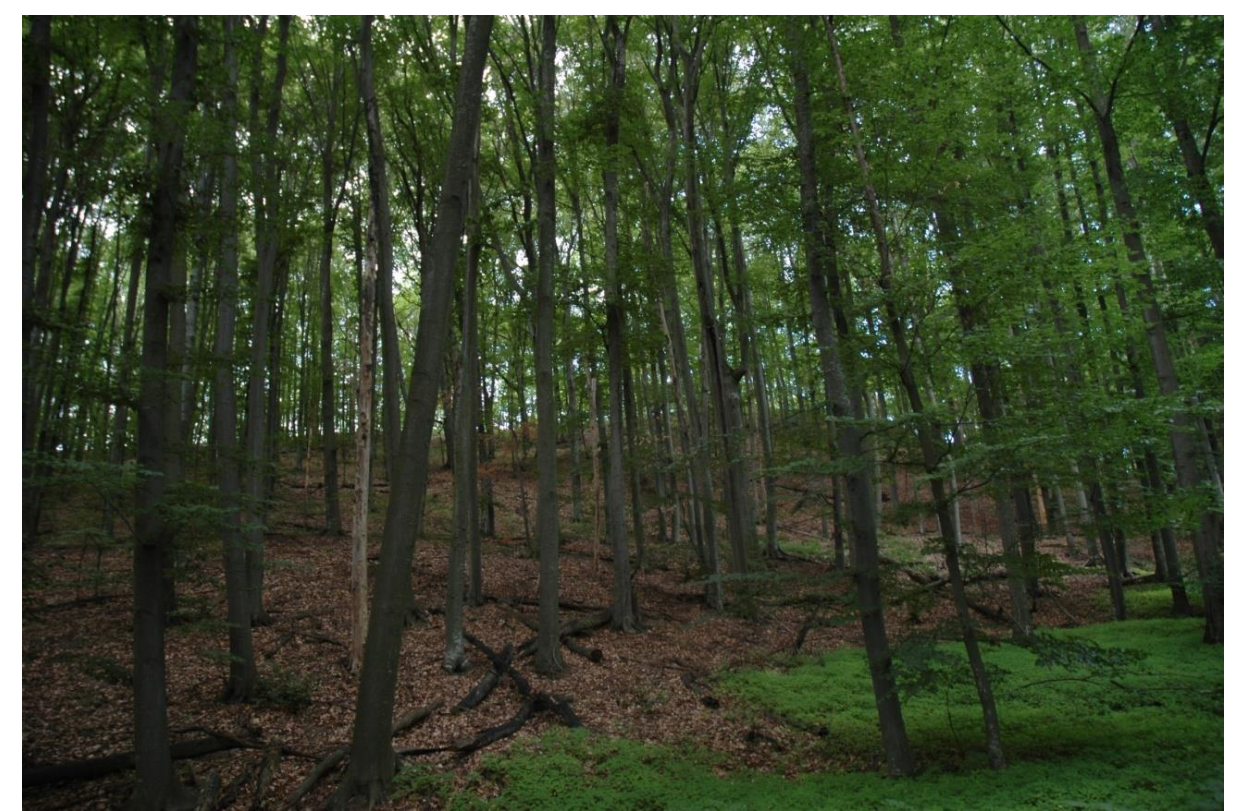

Figure 4. 5314 Hill mixed foliage forest with sessile oak and beech of medium productivity

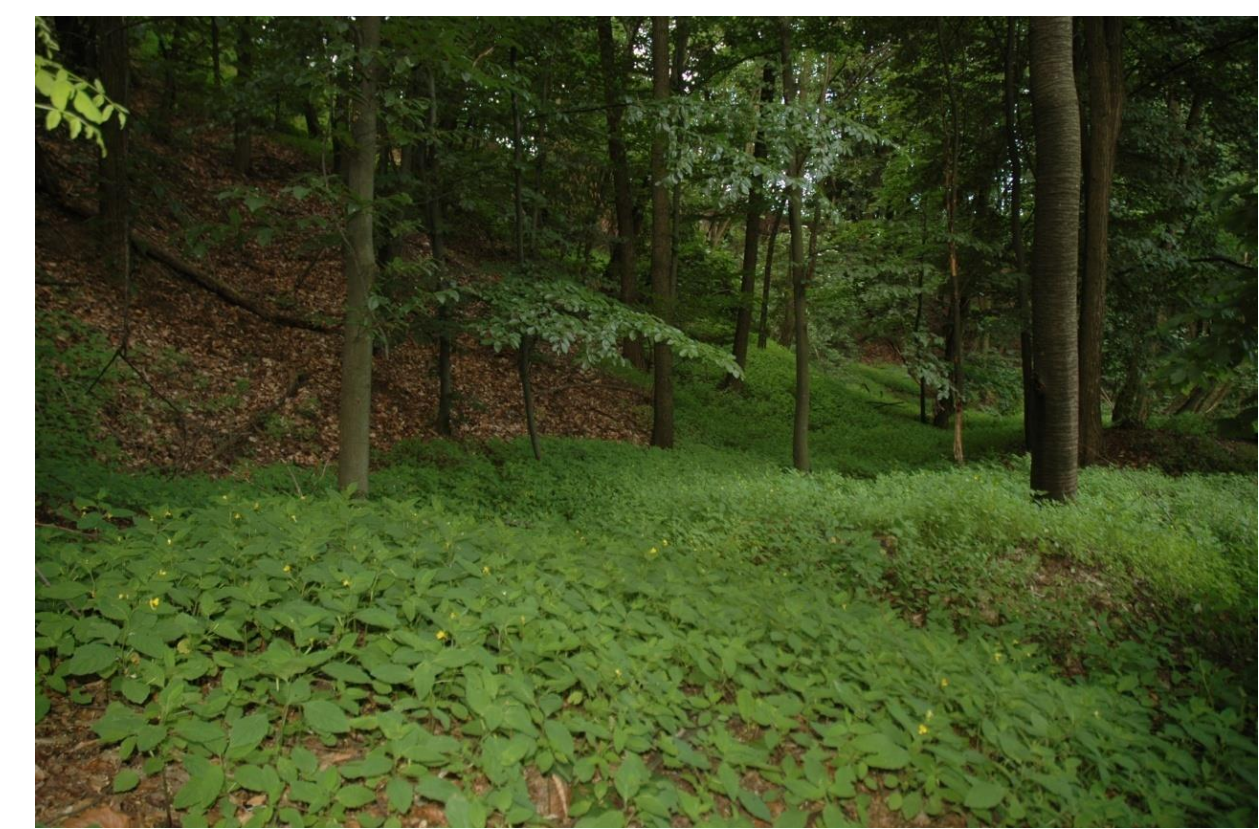

Figure 5. 5314 Hill mixed foliage forest with sessile oak and beech of medium productivity with Impatiens noli-tangere in the herbaceous layer

Floristic composition. Edified species: Fagus sylvatica, Carpinus betulus. Other species: Carpinus betulus, Sanicula europaea, Acer pseudoplatanus, A. platanoides, Ajuga reptans, Euphorbia amygdaloides, Viola reichenbachiana, Rosa canina, Impatiens noli-tangere, Tilia platyphyllos, $T$. tomentosa, Dryopteris filix-mas, Carex pendula, C. sylvatica, C. remota, Alliaria petiolata, Hederea helix, Brachypodium sylvaticum, Salvia glutinosa, Circaea lutetiana, Cardamine impatiens, Sambucus nigra, Athyrium filix-femina, Galium intermedium, G. aparine, G. odoratum, Urtica dioica, Cardamine bulbifera, Quercus petraea, Platanthera bifolia, Atropa bella-donna, 
Populus tremula, Fraxinus excelsior, Epipactis helleborine, Lactuca muralis, Melica uniflora, Rubus hirtus, Dioscorea communis, Lathyrus venetus, Myosotis sylvatica, Digitalis grandiflora, Corylus avellana, Lycopus europaeus, Fragaria vesca, Stachys sylvatica, Neottia nidus-avis.

The conservative value is moderate.

Assessment of the conservation status of 91 Y0 Dacian oak-hornbeam forests natural habitat This habitat is characteristic to Continental and Steppic biogeographical regions, being mentioned in Annex I of Habitats Directive and Annex 2 of OUG no. 57/2007.

\section{Assessment of the conservation status from the surface point of view}

According to the Forestry Management Plan (2019), this habitat has an area of 1100 ha in Pesceana forest, representing less than $1 \%$ of the area occupied at national level (approximately 300,000 ha). The current trend of the habitat area is stable, although in some areas Robinia pseudoacacia has strongly developed. In fact, this species considered invasive occupies the territories where the wood is exploited, in the absence of specific silvicultural works. From the point of view of the occupied surface, we appreciate the favorable conservation status for the $91 \mathrm{Y} 0$ habitat.

Assessment of the conservation status from the structure and function point of view

The characteristic species are Quercus petraea, Carpinus betulus, Tilia tomentosa, Fagus sylvatica, Cardamine bulbifera, Galium intermedium, Melampyrum bihariense, Ranunculus auricomus.

Prunus avium, Tilia platyphyllos, Acer platanoides, A. pseudoplatanus, A. campestre, Sorbus torminalis, Pyrus communis subsp. pyraster vegetate in the arborescent layer. The shrubs layer is defined by species as Corylus avellana, Crataegus monogyna, Cornus sanguinea, Ligustrum vulgare, Sambucus nigra.

The main edifying species of the herbaceous layer are: Arum orientale, Festuca drymeja, Melampyrum bihariense. There are present rare species like orchids: Platanthera bifolia, Epipactis helleborine, Neottia nidus-avis, Cephalanthera longifolia.

The structure and functions of this habitat are in good conditions, without significant degradation. The conservation status from this point of view is favorable.

Assessment of the conservation status from the future perspectives point of view

The intensity of the present and future pressures was analyzed.

The authorized or unauthorized forestry exploitation is a present pressure. There are exploited surfaces where no cleanings have been carried out, preventing the development of the characteristic herbaceous layer. We also report the presence of waste (bags, pets) in the logging areas.

There have been identified alien species with invasive potential: Phytolacca americana, Robinia pseudoacacia, Morus alba, Oxalis corniculata, Ambrosia artemisiifolia, Gleditsia triacanthos, Erigeron annuus, E. canadensis, Xanthium orientale subsp. italicum. Robinia pseudoacacia appears disseminated in the arboretum or forms small plantations, and the other species are present along the forest roads or at the edge of the forest in contact with adjacent meadows.

The possible forms of impact in the future can be: intensification of wood extraction activities, without replanting or replanting with allogenous species; soil erosion caused by the penetration of woodworking and transport machinery; changing the specific floristic composition of the habitat by increasing the population of invasive species; grazing in the forest (herds of cows graze in the meadows at the edge of the forest, but can cross the forest to other grazing areas); collecting rare species, such as orchids; fires.

The cumulative effect of the future impacts on habitat type is: 


\begin{tabular}{|c|c|}
\hline \multicolumn{2}{|c|}{$\begin{array}{c}\text { Current Trends in Natural Sciences } \\
\text { Vol. 9, Issue 18, pp. 139-148, 2020 } \\
\text { https://doi.org/10.47068/ctns.2020.v9i18.019 }\end{array}$} \\
\hline $\begin{array}{l}\text { Current Trends in Natural Sciences (on-line) } \\
\text { ISSN: 2284-953X } \\
\text { ISSN-L: 2284-9521 }\end{array}$ & $\begin{array}{r}\text { Current Trends in Natural Sciences (CD-Rom) } \\
\text { ISSN: 2284-9521 } \\
\text { ISSN-L: 2284-9521 }\end{array}$ \\
\hline
\end{tabular}

$>$ Middle - impacts, respectively current pressures and/or future threats (forest exploitation without replanting or natural restoration; non-native invasive species (allogenous); replanting with non-native trees; natural or man-made fires), will have in the future a significant cumulative medium effect, affecting the long-term viability of the habitat type.

$>$ Low - impacts, respectively current pressures and future threats (grazing in the forest; taking/sampling of terrestrial plants, in general; garbage and solid waste; erosion) will have a low or insignificant cumulative effect, not significantly affecting the long-term viability of the habitat type.

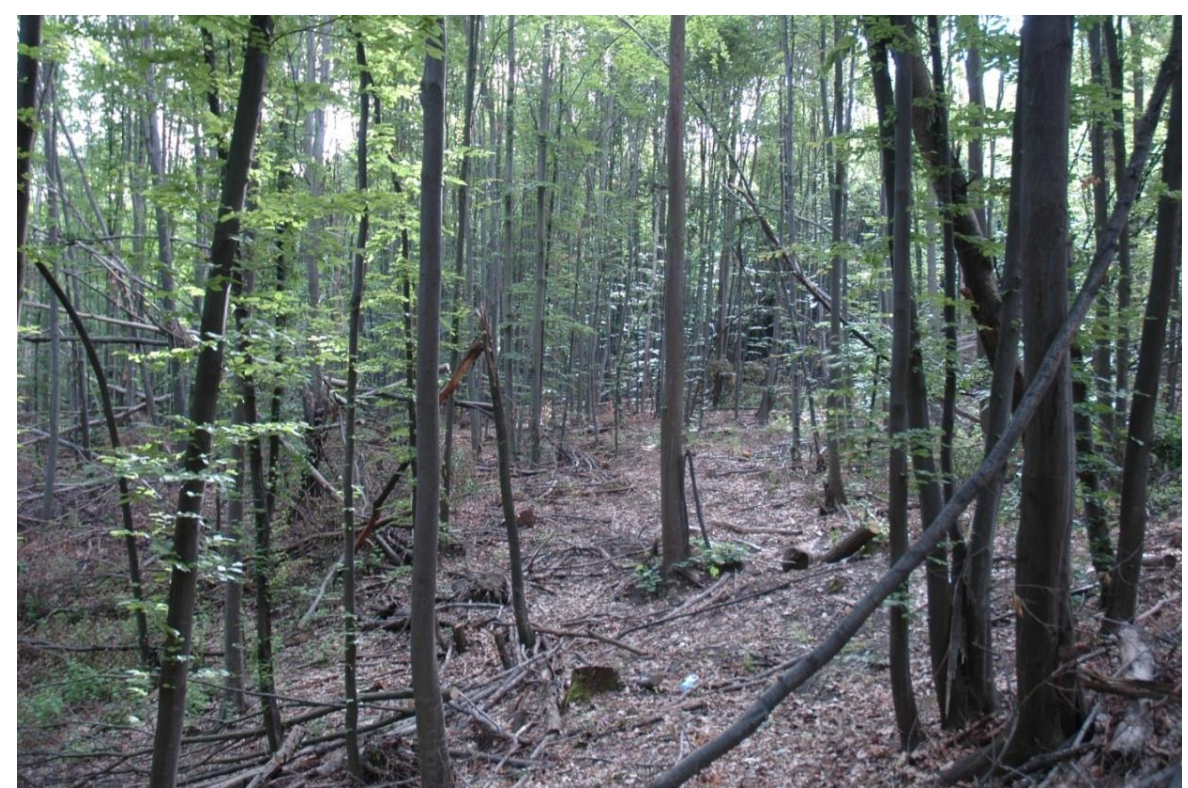

Figure 6. Exploitation of wood without cleaning

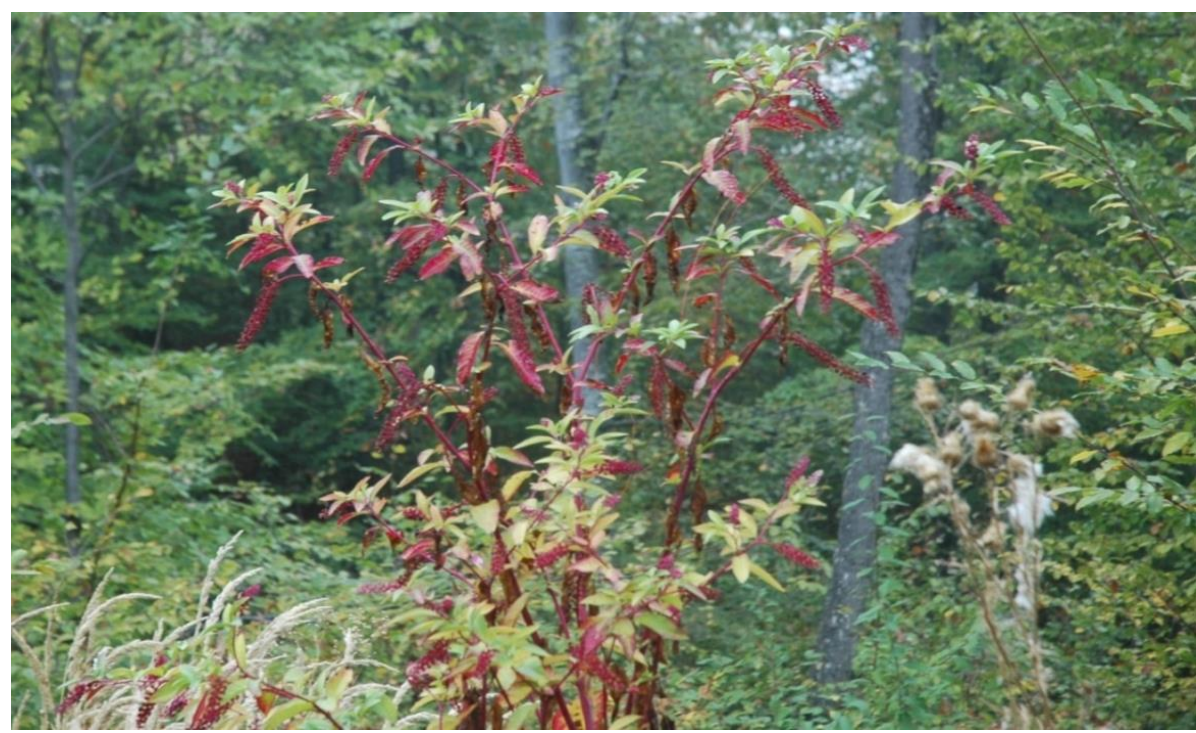

Figure 7. Phytolacca americana $L$. 
The global conservation status of the 91Y0 natural habitat is unfavourable-inadequate due to the intensity of current and future pressures endangering the maintenance of characteristic phytocoenoses, although there are no major changes in the distribution of areas occupied by these plant groupings, and the structure and functions of the habitat are broadly well preserved.

\section{CONCLUSIONS}

The researched area has a special conservative importance considering that a surface of 123 ha of it is included in the site of community importance ROSCI 0296 Drăgășani Hills designated for the protection and conservation both of species and natural habitats.

There is necessary to monitoring and banning the collection of rare species, such as orchids, whose populations in some areas are endangered by expanding forestry exploitations.

Monitoring of invasive species is also important, so as not to change the characteristic structure of the habitat.

Specific forestry measures will be applied, by those who manage the forest, to extract Robinia pseudoacacia in the areas where it is in a co-dominant relationship with the edified species of the arborescent layer (Quercus petraea, Fagus sylvatica, Carpinus betulus).

Deforested areas for anthropogenic or natural reasons must be replanted with species adapted to local conditions, taking into account the fundamental natural type of forest.

Forestry activities will also be monitored so that the impact on plant and animal communities will be minimal (for example, they do not overlap with the birds breeding season).

It is necessary to keep some specimens of dead trees in order to maintain the floristic and faunistic diversity.

It will be forbidden to store waste in the forest or at the edge of the forest, to graze the animals in the forest, to burn the vegetation both in the forest and on the adjacent lands.

It is also necessary to monitor the touristic activities taking into consideration that there is a marked touristic route (Dăești-Râpa Cărămizii-Cotoșmanu), especially for archaeologists who carried out excavations in the area after fossils and to discover the possible ruins of a Dacian fortress in the Cotoșmanu forest.

The implementation of these measures will ensure the conservation of biological diversity in the forest ecosystems of the Pesceana forest, and, in this way, the eco-protective function will be optimized by conserving genetic and specific diversity.

\section{REFERENCES}

Bozga, Șt. B., Lazăr, G., Tudoran, Gh., Stăncioiu, P. T. (2009). Habitate forestiere de importanță comunitară incluse în proiectul LIFE05 NAT/RO/000176: Habitate prioritare alpine, subalpine și forestiere din România. Monitorizarea stării de conservare [Forest habitats of community interest included in the LIFE 05NAT/RO/000176 Project: Alpine, subalpine and forest priority habitats in Romania. Monitoring of the conservation status]. Publishing House Universitatea Transilvania, Braşov.

Chifu, T., Irimia, I., Zamfirescu, O. (2014). Diversitatea fitosociologică a vegetaţiei României. Vegetaţia pădurilor şi tufișurilor (III) [Phytosociological diversity of the Romanian vegetation. Forest and bushes vegetation (III)]. Publishing House Institutul European, Iaşi.

Combroux, I., Schwoerer, Ch. (2007). Evaluarea statutului de conservare a habitatelor şi speciilor de interes comunitar din România-Ghid metodologic [Assessment of the conservation status of community interest habitats and species from Romania-Methodological guide]. Publishing House Balcanic, Timişoara.

Doniţă, N., Popescu, A., Comănescu Paucă, M., Mihăilescu, S., Biriş, I.A. (2005). Habitatele din România [Habitats from Romania]. Publishing House Tehnică Silvică, Bucureşti. 
Gafta, D., Mountford, J. O. coord. (2008). Manual de interpretare a habitatelor Natura 2000 din România [Interpretation manual of the Natura 2000 habitats from Romania]. Publishing House Risoprint, Cluj-Napoca.

Oltean, M., Negrean, G., Popescu, A., Roman, N., Dihoru, Gh., Sanda, V., Mihăilescu, S. (1994). Red list of superior plants from Romania. Institute of Biology Bucharest, Romanian Academy.

Sanda, V., Popescu, A., Stancu, D. (2001). Structura cenotică şi caracterizarea ecologică a fitocenozelor din România [Coenotic structure and ecological characterization of the phytocoenoses from Romania]. Publishing House Conphis, Bucureşti.

Sanda, V., Öllerer, K., Burescu, P. (2008). Fitocenozele din România. Sintaxonomie, structură, dinamică şi evoluţie [Romanian phytocoenoses. Syntaxonomy, structure, dynamics and evolution]. Publishing House Ars Docendi, Bucureşti.

Sârbu, I., Ştefan, N., Oprea, A. (2013). Vascular plants of Romania. An illustrated field guide. Publishing House Victor B Victor, Bucharest.

****, 1952-1969. Flora R.P.R.-R.S.R., Publishing House Romanian Academy, Bucharest.

****, 2007. Ordonanța de Urgență nr. 57/2007 privind regimul ariilor naturale protejate, conservarea habitatelor naturale, a florei şi a faunei sălbatice, Anexa 3b. MO nr. 442/2007 [Emergency Ordinance no. 57/2007 on the regime of natural protected areas, conservation of natural habitats, and of the wild flora and fauna], Annex $3 \mathrm{~b}$. MO no. 442/2007.

****, 2019. Amenajamentul Silvic al Unităţii de Producție V Pesceana realizat de către Ocolul Silvic Drăgășani [The Forest Management of the V Pesceana Production Unit made by the Drăgăşani Forest District].

http://www.anpm.ro/documents/29243/33287047/PUGPesceana-+prima+versiune+final.pdf/94fa080c-2fa1-43df-917b956977802ee4.

http://ww2.bgbm.org/EuroPlusMed/query.asp.

http://ananp.gov.ro/wp-content/uploads/Anexa-Ordin-304-2018-Ghid-elaborare-planuri-de-management.pdf.

https://www.ibiol.ro/posmediu/pdf/Ghiduri/Raportul\%20sintetic\%20privind\%20starea\%20de\%20conservare\%20a\%20s peciilor\%20si\%20habitatelor\%20din\%20RO.pdf.

http://ec.europa.eu/environment/nature/legislation/habitatsdirective/index_en.htm. 